\title{
Upper-rim acidic peptidocalixarenes as crystal growth modifiers
}

Ching Yong Goh, ${ }^{\mathrm{a}}$ Laura Baldini, ${ }^{\mathrm{b}}$ Alessandro Casnati, ${ }^{\mathrm{b}}$ Franca Jones,

Mauro Mocerino, ${ }^{a}$ Mark I. Ogden ${ }^{a}$ Francesco Sansone, ${ }^{b}$ and Rocco

Ungaro. ${ }^{\mathrm{b}}$

a. Department of Chemistry, Curtin University, Perth, Australia

Department of Chemistry

Curtin University

GPO Box U 1987

Perth 6845

\section{AUSTRALIA}

email: m.mocerino@curtin.edu.au and f.jones@curtin.edu.au and m.ogden@curtin.edu.au

b. Dipartimento di Chimica, Università degli Studi di Parma, Parco Area delle Scienze 17/a, 43124 Parma, Italy 


\section{Amino acid-functionalised calixarenes as crystal growth modifiers}

Calix[4]arenes functionalised at the upper rim with acidic amino acid residues are found to have a significant impact on the crystal growth of model mineral systems, calcium carbonate and barium sulfate. The aspartic acid derivative is found to be most efficacious, matching or exceeding the impact of commercial phosphonate-based scale inhibitors. In some cases, the modified morphologies are found to be similar to those induced by proteins isolated from biomineralised systems.

Keywords: calixarenes, crystal growth, calcium carbonate, barium sulfate 


\section{Introduction}

Crystallisation is a fascinating phenomenon in Nature and is of great importance to many industrial processes. It is therefore of no surprise that it is a highly active area of research for both natural and artificial systems. Additives are one of the many methods used by industry to control crystallisation of the desired inorganic $\operatorname{products}(1,2)$ and inhibit unwanted scale formation.(3) However, Nature has had a much longer time to adapt biomineralisation processes to changing functions of various biominerals and can control biomineral formation with much greater finesse. $(4,5)$ Studying how Nature produces such intricate biominerals may provide strategies in preparing new and improved materials and crystal growth modifiers.(6-9)

There is a vast amount of literature describing a variety of biomineral systems, however a complete biomineralisation mechanism is elusive and it is remarkable that a small amount of organic material (comprising proteins and polysaccharides) can have such a large influence over the mineral formation and properties. For example, mollusc shells have $\sim 5 \%$ organic content $(10,11)$ which exerts control over the crystallisation of calcium carbonate $(10,12)$ and gives nacre its unusual mechanical properties $(13)$. One of the emerging themes is that the proteins and organic matrices involved in the formation of biominerals, particularly those associated with calcium carbonate minerals, are of above-average acidity. Many of the these acidic proteins are enriched in aspartic acid and glutamic acid residues with a preference for the former one over other acidic amino acids.(14-16)

Inspired by these observations, the impact of acidic residues, such as aspartic and glutamic acids, and other organic acids have been studied. Dalas et al. found that aspartic acid(17) and glutamic acid(18) could initiate the formation of critical nuclei of $\mathrm{Ca}^{2+}$ and $\mathrm{CO}_{3}{ }^{2-}$ and stabilise vaterite. Later work by Wu et al.(19) with a selection of 
the same amino acids (e.g. aspartic acid, glutamic acid) and organic acids (e.g. succinic acid, acetic acid, glutaric acid) showed the impact of these additives on etch pit morphology during the dissolution of calcite. Their results suggested that the geometry of the additives was important, in particular the distance between calcite surface binding groups (ammonium and carboxylic acid). Elhadj et al. showed that the hydrophilicity and net molecular charge of peptides can be used to predict induced growth rate enhancement of calcite, resulting from a reduced diffusion barrier due to displacement of water molecules at the surface.(20) Modelling studies have shown that even the aspartic acid monomer can act as a catalyst enhancing the crystal growth rate of barite at appropriate concentrations.(21)

In addition to small molecule studies, many researchers have used artificial polymers to mimic natural biomacromolecules found associated with biominerals.(2224) Another approach to spatially arrange moieties known to control crystal growth is to use a macrocyclic, rather than polymeric, framework. While quite different to the natural systems, macrocycles can be functionalised with a number of active groups, and the structure, flexibility, and solubility can be readily controlled. The readilyfunctionalised calixarenes are an attractive option in this context. Both calixarene and resorcinarene frameworks have, in fact, previously been used as crystal growth modifiers. Volkmer et al.(25-28) crystallised calcium carbonate underneath monolayers of amphiphilic resorcinarenes and calixarenes at the air-water interface. By changing the surface pressure, different polymorphs of calcium carbonate crystallised underneath monolayers. From these experiments Volkmer et al.(29) proposed that by varying the charge densities of the monolayers, the desired polymorph of calcium carbonate could be selectively crystallised. Crystallisation of inorganic minerals underneath monolayers 
is of interest as biomimetics for oriented crystallisation at the biomineral-organic matrix interface.(30-33)

Baynton et al.(34) functionalised the upper-rim of calix[4]arenes with sulfonate and phosphonate groups (Figure 1). The phosphonate derivative $\mathbf{1}$ was found to be more potent crystal growth modifier than the sulfonate compound $\mathbf{2}$, as expected, since phosphonates are typically potent crystal growth modifiers for barium sulfate. $(35,36)$ They noted that the phosphonate $\mathbf{1}$ was able to inhibit barium sulfate crystallisation completely even at 13-14 $\mu \mathrm{M}$ concentration while the sulfonate 2 only achieved $34 \%$ inhibition at $200 \mu \mathrm{M}$. The ability of calix[4]arene $\mathbf{1}$ to direct all its phosphonate groups along a surface contributes to its potency, and its efficacy is comparable to that of other small molecule phosphonate inhibitors; hydroxyethylenediphosphonic acid (HEDP), and ethylenediaminetetraphosphonic acid (EDTP), can achieve complete inhibition of barium sulfate at $24 \mu \mathrm{M}$ and $1 \mu \mathrm{M}$ respectively.

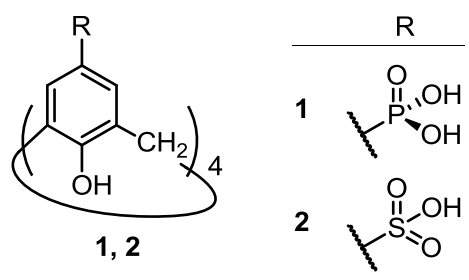

Figure 1. Phosphonate (1) and sulfonate (2) functionalized calix[4]arenes investigated by Massi et al.(37)

Heywood and Ovens(38) studied the impact of O-alkylated derivatives of $p$ sulfonato calix[4]arenes, as the water soluble sodium salt, on calcium carbonate. The authors found that the dominant phase changed from vaterite to calcite as the alkyl chain length of the additive increased.

Quite interestingly, Bartlett et al.(39) showed that amino acid functionalised calix[4]arenes (3-6, Figure 2) were more effective crystal growth modifiers of calcium 
carbonate and calcium oxalate than the equivalent concentration of the amino acid monomers. Furthermore, the aspartic acid derivative (5) was more potent than the alanine (3) or the sarcosine (4) calix[4]arene derivatives. Following from this earlier work, Jones, et al.,(40) investigated the impact of aspartic acid (5) and glutamic acid (6) functionalised calix[4]arenes on calcium carbonate, barium sulfate, and calcium oxalate. Calix[4]arenes $\mathbf{5}$ and $\mathbf{6}$ were found to have an impact on the morphology and crystallisation kinetics of the model minerals investigated at very low concentrations $(<1.5 \mu \mathrm{M})$; the aspartic acid derivative 5 was more potent than the glutamic acid derivative 6.

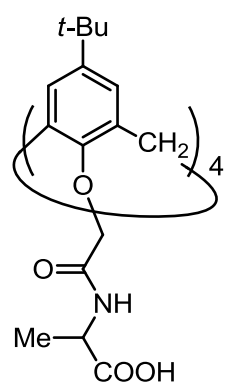

3

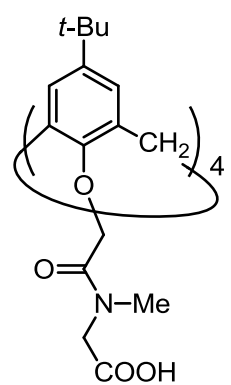

4

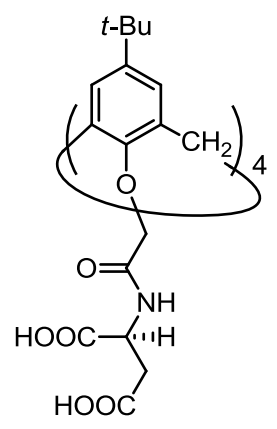

5

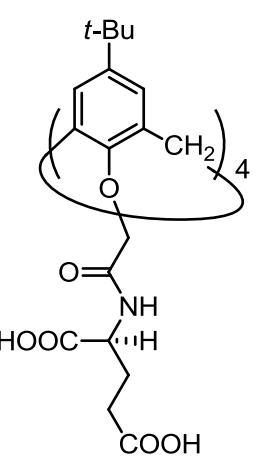

6

Figure 2. Lower-rim functionalised calix[4]arene investigated by Bartlett, et al.(39) (36) and Jones, et al.(40) $(\mathbf{5}, \mathbf{6})$ for crystal growth modification properties of inorganic minerals.

Amino acids can also be linked at the upper-rim of calix[4] arenes(41-43). This may allow for different flexibility and spatial arrangement of amino acids compared to attachment at the lower-rim of calix[4]arenes. Here, we report the syntheses of calix[4]arenes 7a-c, Figure 3. Calixarenes $\mathbf{7 a}$ and $\mathbf{7 b}$ are functionalised with aspartic acid and glutamic acid respectively. Calixarene 7c, functionalised with iminodiacetic acid, is a structural isomer of $\mathbf{7 a}$, which lacks chirality and has a tertiary amide linkage. The impact of these amino acid functionalised calixarenes on model mineral systems, 
calcium carbonate and barium sulfate, were investigated and the results are presented here.
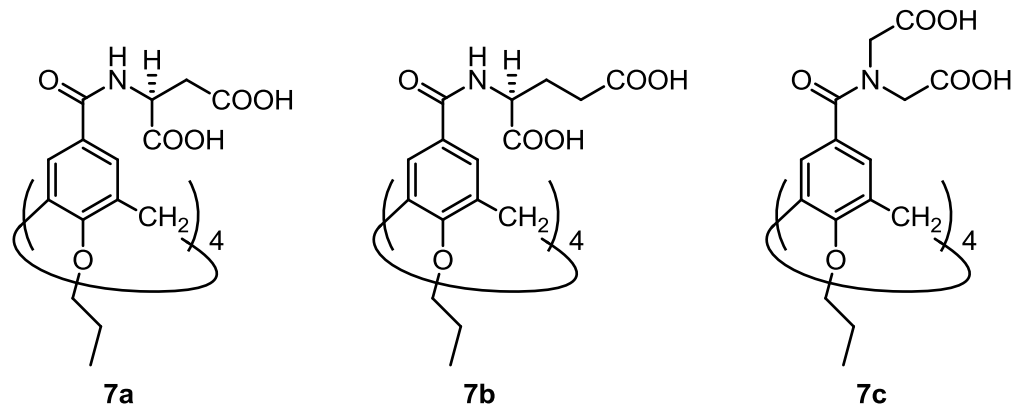

Figure 3. Upper-rim functionalised calix[4]arene used in this project to study the effects of acidic amino acids on the crystallisation of inorganic minerals. Here, the calixarenes were functionalised with aspartic acid (7a), glutamic acid (7b), and imino diacetic acid (7c) and locked in the cone conformer with propyl chains.

\section{Results and Discussion}

\subsection{Synthesis}

Calixarenes 7a-c were prepared following well established procedures for functionalising the upper rim of the calixarene with amino acids and peptides (Scheme 1).(41) The calix[4]arene was locked into the cone conformation by alkylation at the lower rim with propyl groups. Formylation of the upper rim, followed by oxidation, gave the carboxylic acid (8).(41) This was then activated with oxalyl chloride and DMF to give the acid chloride (9), which was then made to react with the $C$-protected amino acids (10-12). The intermediate esters 7a-c were fully characterised, and the results were entirely consistent with the proposed structures. The ester groups were then carefully hydrolysed to give the target amino acid functionalised calixarenes 7a-c. As the yield of the glutamate derivative (13b) was low (34\%) alternative syntheses directly from the acid (8) using peptide-coupling reagents were investigated.(41) Treatment of the calixarene acid $(\mathbf{8})$ with dicyclohexylcarbodiimide and $N$-hydroxybenzotriazole 
followed by diethyl glutamate afforded the calixarene derivative (13b) in a slightly improved yield (41\%), while using $O$-(benzotriazol-1-yl)- $N, N, N^{\prime}, N^{\prime}$-tetramethyluronium hexafluorophosphate as the activating agent, gave a moderate yield $(53 \%)$ of the desired derivative.

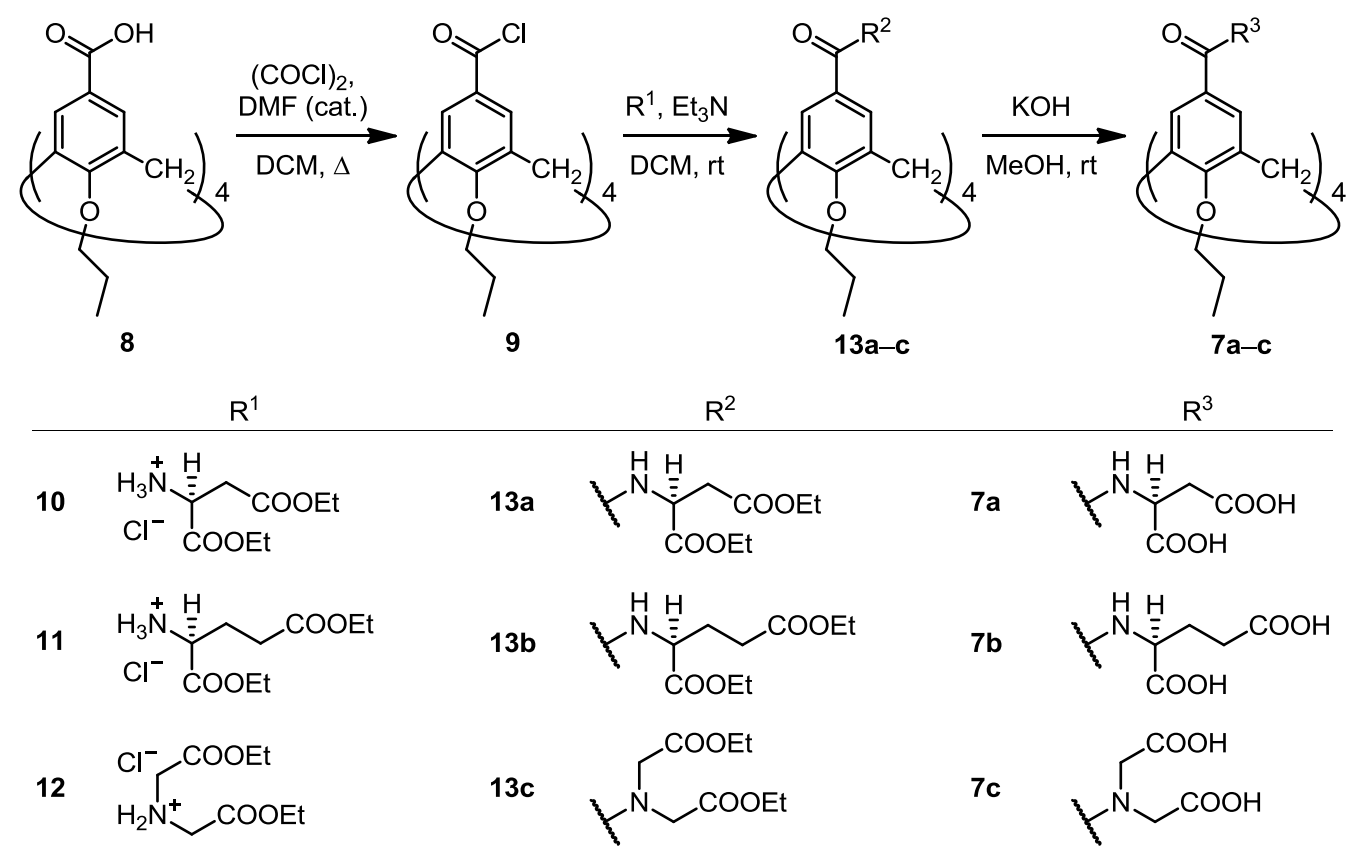

Scheme 1. Preparation of upper-rim, amino acid functionalized calix[4]arene as additives for crystal growth modification

The calixarene additives, $7 \mathbf{a}-\mathbf{c}$, are referred to in the subsequent sections as the carboxylic acids, as this is the form in which they were isolated. It should be noted, however, that the crystal growth studies were carried out at $\mathrm{pH} 6$ for barite, with higher $\mathrm{pH}$ values known to be found in the gas diffusion calcium carbonate experiments.(44) Considering the protonation constants of a monomeric analogue such as $\mathrm{N}$-acetyl aspartic acid $\left(\mathrm{pK}_{\mathrm{a} 1}=3.04, \mathrm{pK}_{\mathrm{a} 2}=4.49\right)(45)$, it is probable that the additives will be substantially deprotonated when interacting with the crystal surfaces. While the impact of $\mathrm{pH}$ is beyond the scope of this study, previous studies have shown that the efficacy of 
carboxylate modifiers decrease with decreasing $\mathrm{pH}$, consistent with the carboxylate being the active moiety.(46)

\subsection{Impact on calcium carbonate crystallisation}

Calcium carbonate was crystallised using the gas-diffusion method.(47) This method of calcium carbonate crystallisation has a well known sequence progressing from the crystallisation of spherical vaterite or needle-like aragonite, which subsequently undergoes a solution-mediated transformation to rhombohedral calcite.(48) In the absence of additives, calcium carbonate precipitated predominantly as calcite (Figure 4a) with the typical rhombohedral shape; however, vaterite was observed in a few instances (Figure 4b). The calixarene additives, $7 \mathbf{a}-\mathbf{c}$, altered the morphology of calcite, even at concentrations less than $1 \mathrm{ppm}$.

The L-aspartic acid additive $\mathbf{7 a}$ was more potent than $\mathbf{7 b}$ and $\mathbf{7 c}$. The impact of 7a was evident even at the lowest concentration investigated $(0.4 \mu \mathrm{M}$, Figure $4 \mathrm{c})$. Above $1.2 \mu \mathrm{M}$ (Figure 4e) any indication of the general rhombohedral profile was lost. Similarly, the edges became more rounded with increasing additive concentrations as found for an aspartic acid rich protein.(49) In contrast to calcite particles grown in the presence of the lower-rim analogue 5 (Figure 2), the calcite particles here did not exhibit notches along the edges of the rhombohedron.

The L-glutamic derivative $\mathbf{7 b}$ appeared to have less impact on the morphology of the calcite particles than $\mathbf{7 a}$. The calcite particles grown in the presence of $\mathbf{7 b}$ showed notches along one corner (Figure 4f) or edge (Figure 4h) of the rhomb and had microsteps along the faces. At the highest concentration studied (1.2 $\mu \mathrm{M})$ (Figure $4 \mathrm{~h})$, the calcite rhomb retained much of its edges with mild stepped faces like those grown in the presence of the lower-rim analogue 6 at $1.4 \mu \mathrm{M}$. However, the upper-rim 
calix[4]arene $\mathbf{7 b}$ appears to be more potent than the lower-rim calix[4]arene $\mathbf{6}$. The stepped morphology resembles that of calcite grown in the presence of nacre proteins (isolated from the aragonitic layer of red abalone, Haliotis rufescens), in particular the aspartic acid/asparagine- and glycine-rich protein 'AP8'.(50, 51)

The iminodiacetic acid derivative $7 \mathbf{c}$ required a greater concentration to have an impact on the calcite morphology. At concentrations of $0.8 \mu \mathrm{M}$ of $\mathbf{7 c}$, stepped faces begin to appear on the calcite particles (Figure 4j); at lower concentrations, the calcite particles appeared to retain the typical rhombohedral shape (not shown here). Interestingly, spherical particles (Figure 4i), presumably vaterite, were also observed for calcium carbonate grown in the presence of $7 \mathbf{c}(0.4 \mu \mathrm{m})$. Vaterite phases have been known to be stabilised by aspartic acid,(17) glutamic acid,(18) poly(aspartic acid)(52) and egg ovalbulmin(53) preventing it from transforming into calcite. Calixarene 7c was not used in the original work by Jones et al.,(40) so no comparison can be made to a lower-rim analogue. 

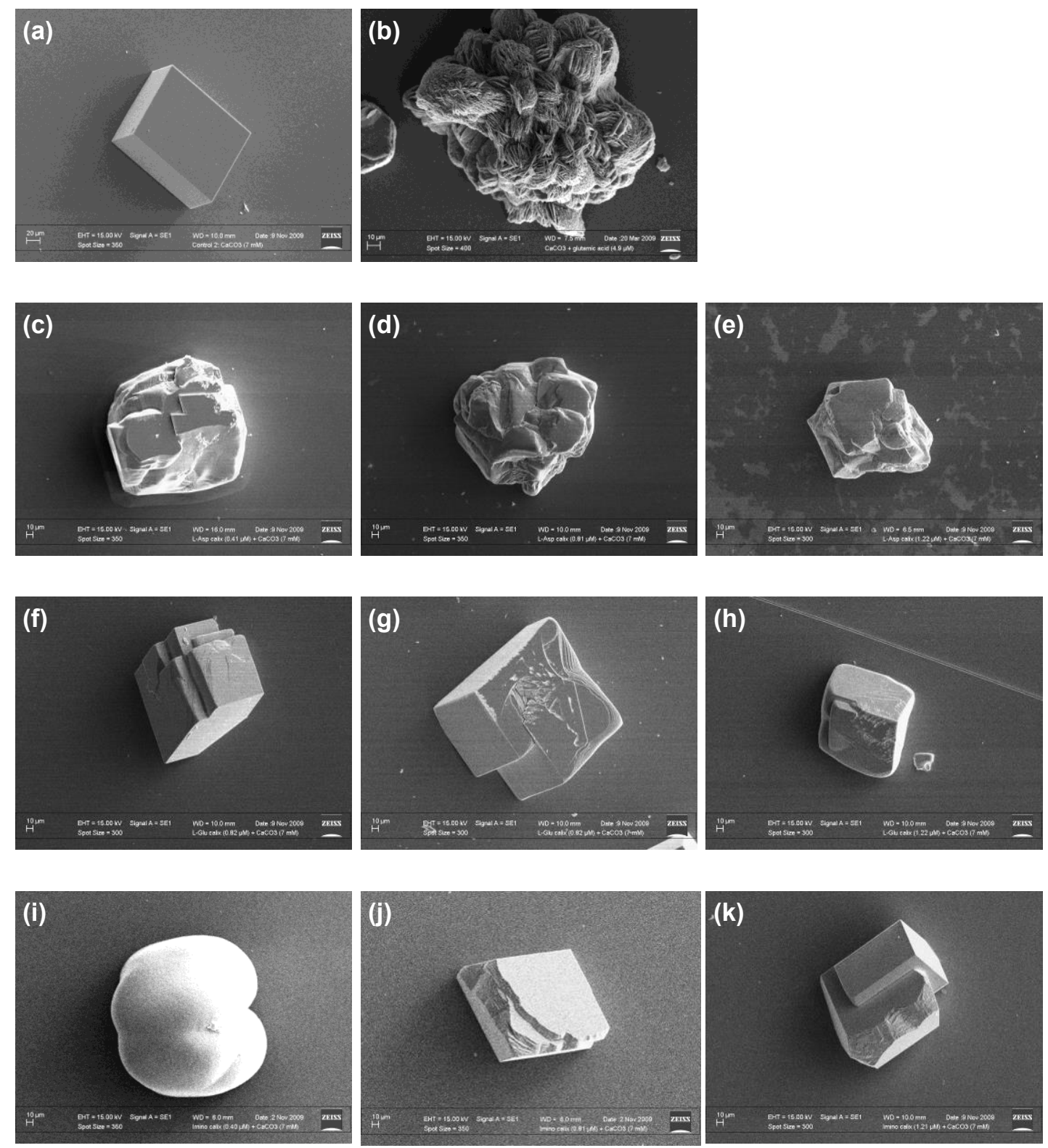

Figure 4. SEM micrographs of calcium carbonate in the absence of additives: (a) calcite (major polymorph) and (b) vaterite (observed occasionally). Calcite morphology in the presence of amino acid functionalised calix[4]arene: L-Asp 7a at (c) $0.4 \mu \mathrm{M}$, (d) $0.8 \mu \mathrm{M}$, (e) $1.2 \mu \mathrm{M}$; L-Glu 7b at (f) $0.4 \mu \mathrm{M}$, (g) $0.8 \mu \mathrm{M}$, (h) $1.2 \mu \mathrm{M}$; iminodiacetate 7c at (i) $0.4 \mu \mathrm{M}$, (j) $0.8 \mu \mathrm{M}$, (k) $1.2 \mu \mathrm{M}$. 


\subsection{Impact on barium sulfate crystallisation}

\subsubsection{Impact on crystal growth kinetics}

The impact of calix[4]arene additives $\mathbf{7 a}$ and $\mathbf{7 b}$ on barium sulfate crystallisation was first determined by desupersaturation experiments.(54) Here, the crystallisation process was followed by monitoring the decrease of conductivity vs time of a supersaturated solution of barium sulfate. The rates determined from these experiments were then plotted as a function of additive concentration (Figure 5); the aspartic acid derivative 7a was found to be approximately ten times more potent than the glutamic acid derivative $\mathbf{7 b}$ at inhibiting barium sulfate crystallisation. The calixarene 7a was able to achieve complete inhibition (over the time scale of the experiment) at $0.3 \mu \mathrm{M}$ whereas $\mathbf{7 b}$ required 3.9 $\mu \mathrm{M}$ to do the same. The glutamic acid derivative $\mathbf{7 b}$ has a comparable inhibition potency with respect to to the lower-rim derivative 5 (which achieved complete inhibition at $3.6 \mu \mathrm{M})$. On the other hand, the aspartic acid derivative $7 \mathbf{a}$ is at least ten times more potent than its lower-rim analogue $\mathbf{6}$ (which achieved complete inhibition at $3.6 \mu \mathrm{M})$. Calix[4]arene 7a is even slightly more potent than the phosphonate calixarene 1 (complete inhibition at $13-14 \mu \mathrm{M}$ ) and is approaching the efficacy of some organophosphonate inhibitors; under the conditions used here, HEDP can achieve complete inhibition at $24 \mu \mathrm{M}$ while EDTP only requires $1 \mu \mathrm{M}$.(36) 


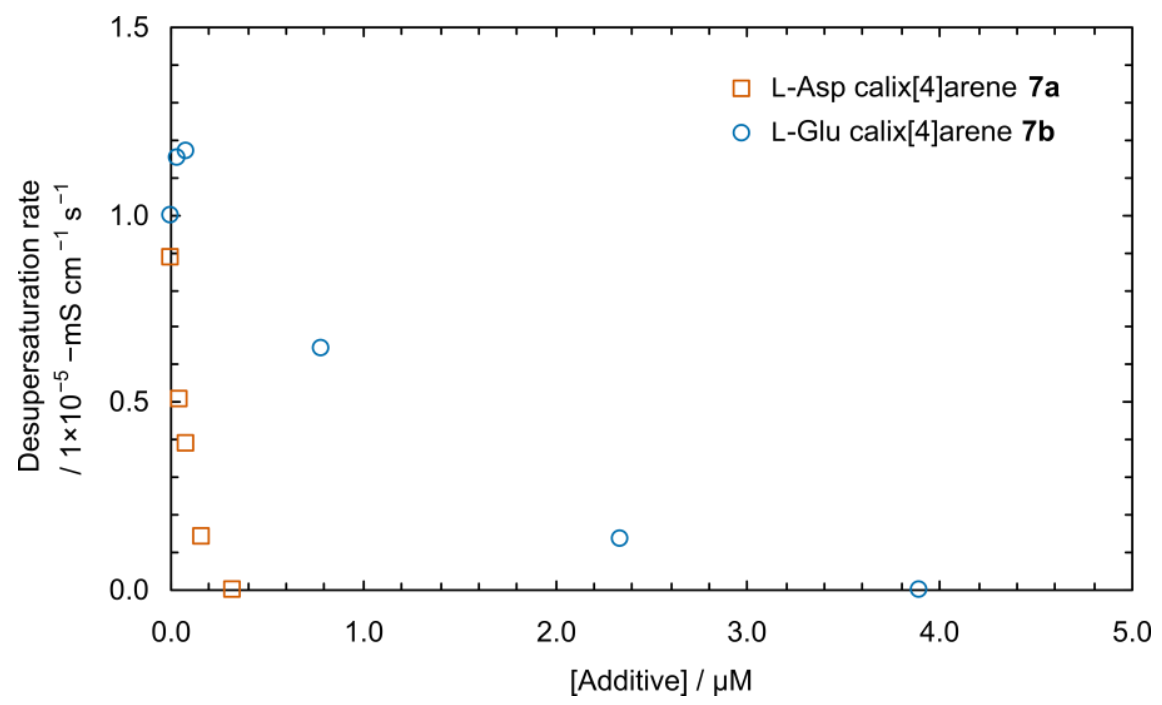

Figure 5. Desupersaturation rates of a supersaturated barium sulfate solution as a function of the concentration of upper-rim amino acid functionalised calix[4] arene additives $\mathbf{7 a}$ and $\mathbf{7 b}$.

While aspartic and glutamic acids are often associated together as 'acidic components' in proteins associated with biominerals,(55) some authors have observed differences in the impact of the two amino acids(56) and their homo-oligomers.(57). Of the additives described here, it may be that the aspartic acid groups at the upper rim of calix[4]arene give a more appropriate bite and therefore a better chelating ability to barium ions on the surface of the nucleating crystals, thus efficiently inhibiting crystallization. The higher inhibition potency of $\mathbf{7 a}$ compared to $\mathbf{5}$ could be ascribed to the different distances of the $\mathrm{COOH}$ groups of aspartic acid at the upper compared to those of the lower rim derivatives.

\subsubsection{Impact on barium sulfate morphology}

The morphologies of the barium sulfate crystals produced in the desupersaturation experiments were investigated. In the absence of any additives, the barium sulfate particles had the expected 'pillow-shaped' morphology with rounded ( $h k 0)$ faces and (001) ends (Figure 6a). The two additives investigated here, $7 \mathbf{a}$ and $\mathbf{7 b}$, 
showed only some moderate impact on the morphology of barium sulfate but were highly potent in the inhibition of barium sulfate crystallisation.

Barium sulfate grown in the presence of $\mathbf{7 a}$ was found to form polycrystalline assemblies. These crystals (Figure 6) were isolated at the end of the desupersaturation experiments. At additive levels of $0.16 \mu \mathrm{M}$ and less, some of the clusters appeared lengthened along the $c$-axis exceeding the typical 2:1 c/a aspect ratio (refer to Jones et al.(58) for micrographs of control barium sulfate particles at $S=25$ ). At higher concentrations the barium sulfate particles are smaller and have distorted morphologies; this is especially true at additive levels of $0.8 \mu \mathrm{M}$ (Figure $6 \mathrm{~h}$ ). This is consistent with the inhibitory effect of the additive. Where the desupersaturation experiments did not result in a precipitate at the end of the experiment (at additive levels greater then $0.8 \mu \mathrm{M})$, an aliquot of the solution was allowed to stand for up to 15 days over a microscope slide. Only at additive levels of $0.16 \mu \mathrm{M}$ (Figure $6 \mathrm{~d}, \mathrm{e}$ ) were polycrystalline 'ribbons' observed. The 'ribbons' appeared to be comprised of smaller orthorhombiclike particles. These polycrystalline 'ribbons' resemble results obtained by Heywood and $\operatorname{Mann}(59,60)$ who crystallised barium sulfate underneath compressed $n$-eicosyl sulfate monolayers (43-47 $\mathrm{mN} \mathrm{m}^{-1}$ ) with the (100) face parallel to the monolayer. However, it is not clear from the micrographs (Figure 6d,e) if there is selectivity for a particular crystal face. The morphology of barium sulfate crystallised in the presence of 7a retained its typical rectangular shape (at concentrations less than $0.31 \mu \mathrm{M}$ ): in contrast barium sulfate crystallised in the presence of the lower-rim analogue $\mathbf{5}$ had elongated morphologies. Both aspartic acid-based additives resulted, however, in polycrystalline barium sulfate particles. 

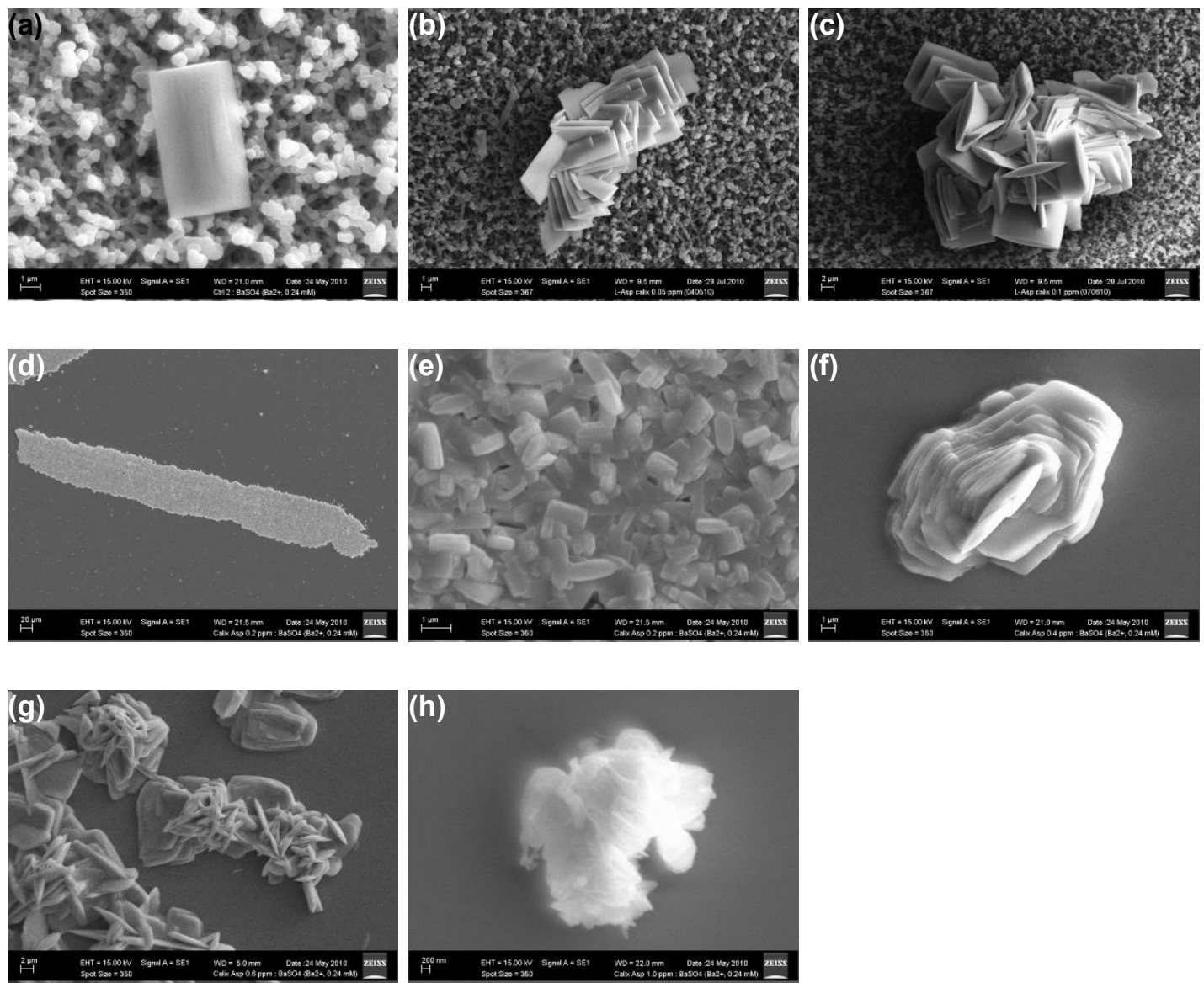

Figure 6. SEM micrographs showing the impact on the morphology of barium sulfate by L-Asp calix[4]arene 7a at, (a) $0 \mu \mathrm{M}$ (control), (b) $0.04 \mu \mathrm{M}$, (c) $0.08 \mu \mathrm{M}$, (d) $0.16 \mu \mathrm{M}$, (e) $0.16 \mu \mathrm{M}$ close-up, (f) $0.31 \mu \mathrm{M}$, (g) $0.49 \mu \mathrm{M}$, and (h) $0.81 \mu \mathrm{M}$. At L-Asp calix[4]arene concentrations of $0.16-0.81 \mu \mathrm{M}$, the filtrates from the conductivity experiments were allowed to stand for 5-14 days over coverslips.

The morphology of barium sulfate grown in the presence of the glutamic acid derivative $\mathbf{7 b}$ was similar to those grown in the presence of $\mathbf{7 a}$. For low concentrations of the additive $(<0.39 \mu \mathrm{M})$, the barium sulfate was polycrystalline and the constituents of the clusters had a lengthened $c$-axis (Figure $7 \mathrm{a}-\mathrm{c}$ ), similar to that crystallised in the presence of the lower-rim analogue 7. At higher concentrations $(>0.78 \mu \mathrm{M})$, the presence of the glutamic acid derivative $\mathbf{7 b}$, like $\mathbf{7 a}$, resulted in barium sulfate particles that were rounded and did not have a rectangular shape (Figure $7 \mathrm{~d}-\mathrm{e}$ ). 

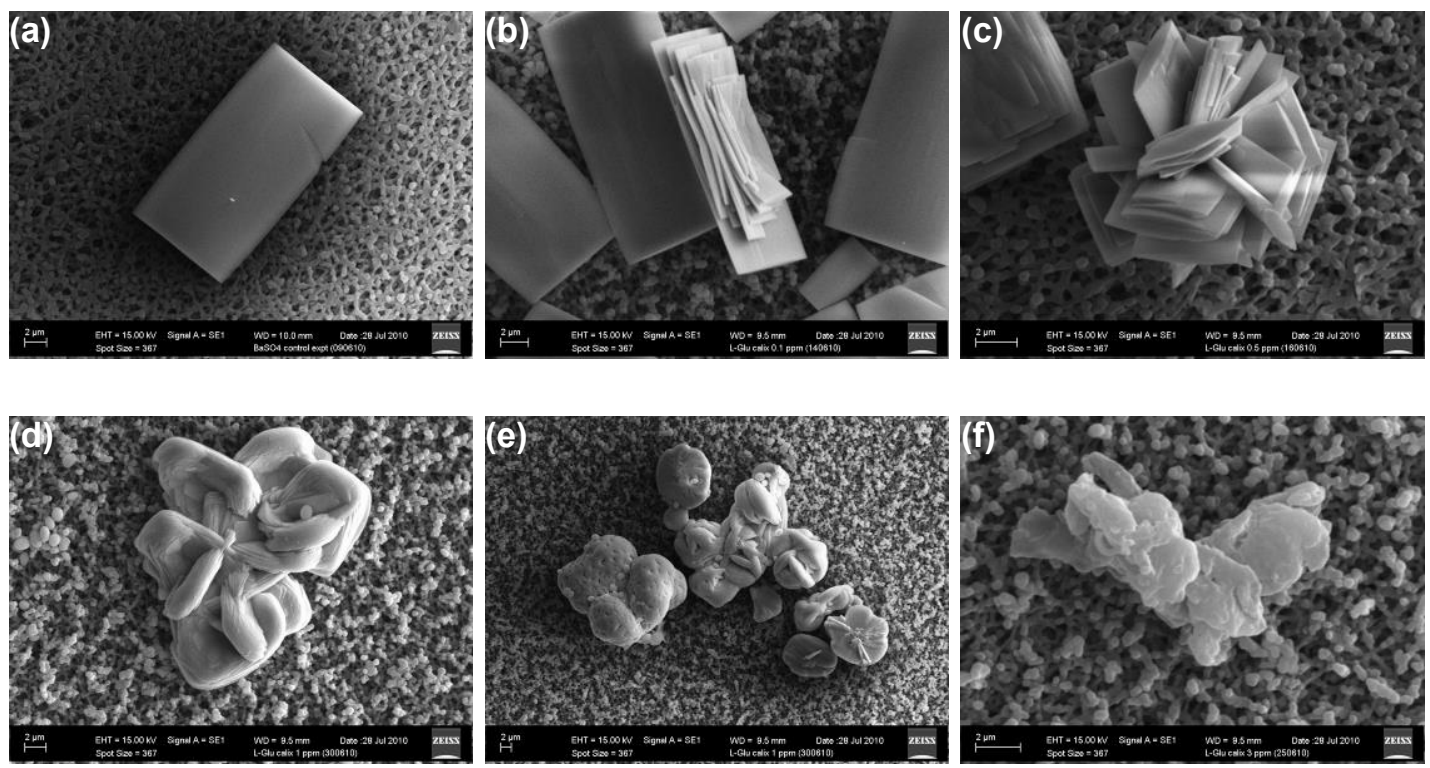

Figure 7. SEM micrographs showing the impact on the morphology of barium sulfate by L-Glu calix[4]arene 7b at, (a) $0 \mu \mathrm{M}$ (control), (b) $0.08 \mu \mathrm{M}$, (c) $0.39 \mu \mathrm{M}$, (d) $0.78 \mu \mathrm{M}$, (e) $0.78 \mu \mathrm{M}$, and (f) $2.33 \mu \mathrm{M}$. Where the L-Glu calix[4]arene concentration was at $2.33 \mu \mathrm{M}$, the filtrate from the conductivity experiments were allowed to stand over a coverslip for 14 days.

\subsubsection{Impact on nucleation kinetics}

The induction time for barium sulfate crystallisation was determined by a light scattering method,(61) as it can not be reliably determined from desupersaturation curves.(62) The results indicated that the presence of additives lengthened the induction time compared with control experiments. Mullin(62) defines the induction time to include the time taken to form stable nuclei and the growth of the nuclei to a measurable size. Therefore, an increase in the induction time can be an indication of an increase in time required to form stable nuclei and/or time required for the nuclei to grow to a detectable size. It has also been found that increases in induction time can be related to increases in the surface free energy of the critical nuclei. This implies that additives that impact on the induction time are adsorbing onto the critical nuclei and altering their surface energies. 
The results (Table 1) showed that the amino acid functionalised calixarene additives lengthened the induction time of barium sulfate. The aspartic acid derivative 7a (Figure 8) doubled the induction time for barium sulfate at a concentration of $0.04 \mu \mathrm{M}$. The glutamic acid derivative $7 \mathbf{b}$ (Figure 9) was less potent requiring ten times the additive level of $\mathbf{7 a}$ to induce a doubling of the induction time. Thus, these additives have an impact on both the nucleation events and crystal growth phase of barium sulfate. This suggests that both the L-aspartic acid and L-glutamic calixarene additives acted as inhibitors of both bulk nucleation and crystal growth.

Table 1. Approximate induction times for the autonucleation of $\mathrm{BaSO}_{4}$ in the presence of calixarene additives determined by UV-visible spectroscopy.

\begin{tabular}{lll}
\hline Additive & Concentration & Approximate \\
& $/ \mu \mathrm{M}$ & induction time \\
& & $/ \mathrm{s}$ \\
\hline None (control) & - & 100 \\
L-Asp calix[4]arene 7a & 0.04 & 200 \\
L-Glu calix[4]arene 7b & 0.39 & 250 \\
L-Glu calix[4]arene 7b & 0.58 & 700 \\
L-Glu calix[4]arene 7b & 0.78 & 900 \\
\hline
\end{tabular}




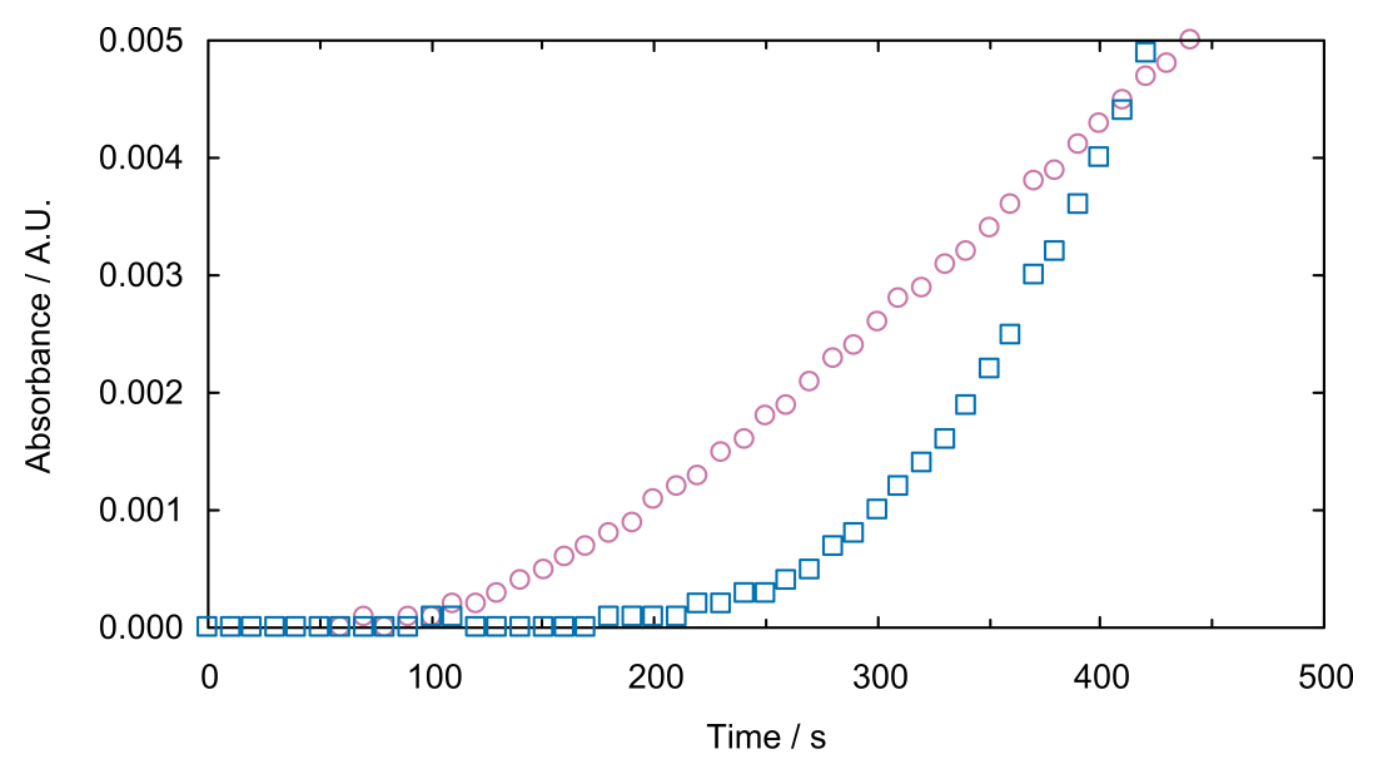

○ Control

$\square$ L-Asp calix. 7a $(0.05$ ppm)

Figure 8. Determination of induction time for autonucleated barium sulfate in the presence of L-aspartic acid functionalised calix[4]arenes (7a). Absorbance of reaction solution measured overtime with additive levels at $0 \mu \mathrm{M}$ of additive (control) and $0.04 \mu \mathrm{M}(0.05 \mathrm{ppm})$.

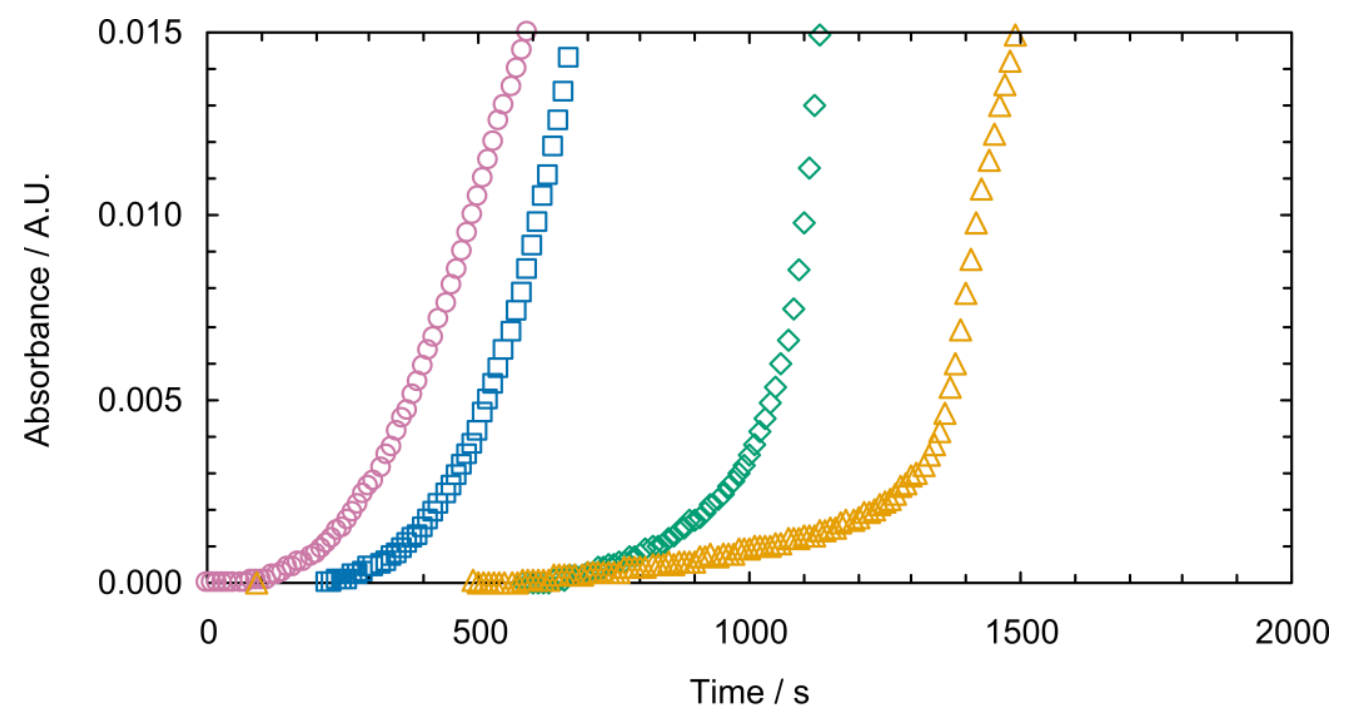
Control
L-Glu calix. 7b $(0.05 \mathrm{ppm})$

$\diamond \quad$ L-Glu calix. 7 b $(0.75 \mathrm{ppm})$

$\triangle$ L-Glu calix. 7b (1.00 ppm)

Figure 9. Determination of induction time for autonucleated barium sulfate in the presence of L-glutamic acid functionalised calix[4]arene (7b). Absorbance of reaction solution measured overtime with additive levels from $0 \mu \mathrm{M}$ of additive (control) to $0.78 \mu \mathrm{M}(1 \mathrm{ppm})$. 


\section{Conclusions}

The amino acid functionalised calixarenes, $7 \mathbf{a}-\mathbf{c}$, had an impact on the crystallisation of model mineral systems, calcium carbonate and barium sulfate. The aspartic acid functionalised calixarene 7a appeared to affect the morphology of calcium carbonate more than the glutamic acid derivative $\mathbf{7 b}$. Whilst $\mathbf{7 b}$ appeared to behave similarly to its lower-rim counter part in the crystallisation of calcium carbonate, $7 \mathbf{a}$ resulted in a different calcite morphology compared with its lower-rim analogue. The iminodiacetic acid derivative 7c required a higher additive level to alter the calcite morphology. Barium sulfate grown in the presence of $\mathbf{7 a}$ and $\mathbf{7 b}$ gave similar morphologies. The kinetics of crystallisation, however suggested that the aspartic calixarene 7a was a more potent crystal growth inhibitor than the glutamic calixarene $\mathbf{7 b}$. The aspartic derivative 7a was also a more potent barium sulfate growth inhibitor than the lower-rim analogue; 7b showed similar potency to its lower-rim analogue. The higher activity of the upper rim aspartic acid derivatives 7a compared to lower rim analogs $\mathbf{5}$ could be related to the different rigidity and bite-distance of the chelating carboxylic groups. In general, it was also confirmed that the high density of carboxylate groups given by the simultaneous presentation of aspartic/glutamic residues onto a cone-calix[4]arene greatly enhance the inhibition of calcite or barite crystal growth in solution.

\section{Experimental}

\subsection{General remarks}

Reagents were used as purchased from the manufacturer or supplier. MilliQ water, having a resistance of $0.055 \mathrm{~cm} / \Omega$, was used throughout crystallisation experiments. Solvents for reactions and column chromatography were purified according to Armarego and Chai.(63) 
Column chromatography was performed on Merck silica gel 60 (230-400 mesh).

Reactions were monitored by TLC on aluminium backed Merck silica gel $60 \mathrm{~F}_{245}$ with detection by UV (for aromatic compounds), $1 \% \mathrm{FeCl}_{3}$ solution (for phenolic compounds), Brady's reagent(64) (for aldehydes), iodine vapour (general purpose) and/or $1 \%$ potassium permanganate solution (general purpose).

Proton and carbon NMR spectra were acquired at room temperature on a Varian Gemini ${ }^{\mathrm{TM}} 200\left({ }^{1} \mathrm{H} 200 \mathrm{MHz},{ }^{13} \mathrm{C} 50 \mathrm{MHz}\right)$ or a Bruker Avance ${ }^{\mathrm{TM}}$ III 400 NanoBay $\left({ }^{1} \mathrm{H}\right.$ $400 \mathrm{MHz},{ }^{13} \mathrm{C} 100 \mathrm{MHz}$ ) spectrometer. NMR spectra were referenced to their respective solvents:(65, 66) chloroform- $d\left(\mathrm{CDCl}_{3},{ }^{1} \mathrm{H}, \delta 7.26 \mathrm{ppm} ;{ }^{13} \mathrm{C}, \delta 77.16 \mathrm{ppm}\right)$; dimethyl sulfoxide- $d_{6}\left(\mathrm{CD}_{3} \mathrm{SOCD}_{3},{ }^{1} \mathrm{H}, \delta 2.50 \mathrm{ppm} ;{ }^{13} \mathrm{C}, \delta 39.52 \mathrm{ppm}\right)$. NMR signal assignments were assisted by literature data, DEPT or DEPTQ-135, and 2-dimensional NMR experiments $\left({ }^{1} \mathrm{H}-{ }^{1} \mathrm{H}\right.$ COSY, ${ }^{1} \mathrm{H}-{ }^{13} \mathrm{C}$ HSQC,${ }^{1} \mathrm{H}-{ }^{13} \mathrm{C}$ HMBC, ${ }^{1} \mathrm{H}-{ }^{1} \mathrm{H}$ TOCSY $)$. Multiplicity is assigned as follows: $\mathrm{s}=$ singlet, $\mathrm{d}=$ doublet, $\mathrm{t}=$ triplet, $\mathrm{q}=$ quartet, $\mathrm{sxt}=$ sextet, br $=$ broad.

Attenuated total reflectance Fourier Transform infrared (ATR-FT-IR) spectra were acquired on a PerkinElmer Spectrum 100 series spectrometer with a Universal ATR sampling accessory fitted with a ZnSe/diamond composite crystal. Spectra were recorded at a resolution of $4 \mathrm{~cm}^{-1}$ in the range of $4000-650 \mathrm{~cm}^{-1}$ with 16 scans accumulated. ATR correction was applied to the spectra.

Elemental analysis was performed by the Central Science Laboratory, University of Tasmania.

Melting ranges of solid samples were determined using a Barnstead/Electrothermal digital melting point apparatus (model 9100) at atmospheric pressure. Melting ranges 
were measured in duplicate then averaged. 25,26,27,28-tetra-n-propoxycalix[4]arene5,11,17,23-tetracarbonyl chloride (9) was prepared according to literature.(41)

\subsection{Preparation of amino acid functionalised calixarenes for crystal growth modification studies}

4.2.1 Preparation of 25,26,27,28-tetra-n-propoxycalix[4]arene-5,11,17,23tetrakis-\{(2S)-2-[(carbonyl)amino]\}butanedioic acid diethyl ester (13a)

A solution of L-aspartic acid diethyl ester hydrochloride (502 mg, $2.22 \mathrm{mmol}$ ) and triethylamine $(0.61 \mathrm{~mL}, 440 \mathrm{mg}, 4.35 \mathrm{mmol})$ dissolved in dichloromethane $(15 \mathrm{~mL})$ was added dropwise to a cold stirring solution of the acid chloride 9 (413 mg, $0.49 \mathrm{mmol})$ dissolved in dichloromethane $(15 \mathrm{~mL})$ over 15 minutes. The reaction mixture was stirred at room temperature under an argon atmosphere over the weekend. The reaction mixture was diluted with hydrochloric acid $(1 \mathrm{~m}, 30 \mathrm{~mL})$ and stirred for 30 minutes. The organic phase was separated and washed with hydrochloric acid $(2 \times 15 \mathrm{~mL})$ then saturated sodium chloride $(30 \mathrm{~mL})$, dried $\left(\mathrm{MgSO}_{4}\right)$, and concentrated in vacuo. Purification of the brown residue by column chromatography [dichloromethane/acetone (9:1, v/v)] afforded a glassy yellow solid (318 mg, $0.22 \mathrm{mmol}, 44 \%$ yield) which crystallised on standing: mp $120-130{ }^{\circ} \mathrm{C}$ (material crystallised from glassy material); ${ }^{1} \mathrm{H} \mathrm{NMR}\left(400 \mathrm{MHz}, \mathrm{CDCl}_{3}\right) \delta 7.16(\mathrm{~d}, J=2.1 \mathrm{~Hz}$, $4 \mathrm{H}, \mathrm{Ar}-H), 7.04(\mathrm{~d}, J=2.1 \mathrm{~Hz}, 4 \mathrm{H}, \mathrm{Ar}-H), 7.01(\mathrm{~d}, J=7.9 \mathrm{~Hz}, 4 \mathrm{H}, \mathrm{N}-H), 4.88$ (apparent dt, 4H, NCH), $4.46\left(\mathrm{~d}, J=13.6 \mathrm{~Hz}, 4 \mathrm{H}, \mathrm{H}_{\mathrm{ax}}, \mathrm{Ar}-\mathrm{CH}_{2}-\mathrm{Ar}\right), 4.25-4.09$ (overlapped m, 16H, $\mathrm{OCH}_{2} \mathrm{CH}_{3}$ ), $3.88\left(\mathrm{t}, J=7.5 \mathrm{~Hz}, 8 \mathrm{H}, \mathrm{OCH}_{2} \mathrm{CH}_{2}\right.$ ), 3.27 (d, $J=$ 13.6 Hz, 4H, $\left.\mathrm{H}_{\mathrm{eq}}, \mathrm{Ar}-\mathrm{CH}_{2}-\mathrm{Ar}\right), 3.02$ (dd, $\left.J=4.4,16.7 \mathrm{~Hz}, 4 \mathrm{H}, \mathrm{H}^{\prime}, \mathrm{CH}_{2} \mathrm{C}=\mathrm{O}\right), 2.94$ (dd, $\left.J=5.4,16.7 \mathrm{~Hz}, 4 \mathrm{H}, \mathrm{H}^{\prime \prime}, \mathrm{CH}_{2} \mathrm{C}=\mathrm{O}\right), 1.90\left(\mathrm{sxt}, J=7.5 \mathrm{~Hz}, 8 \mathrm{H}, \mathrm{OCH}_{2} \mathrm{CH}_{2}\right), 1.25$ (overlapped, apparent q, 24H OCH${ }_{2} \mathrm{CH}_{3}$ ), $0.99\left(\mathrm{t}, \mathrm{J}=7.5 \mathrm{~Hz}, 12 \mathrm{H} \mathrm{OCH}_{2} \mathrm{CH}_{2} \mathrm{CH}_{3}\right.$ ); ${ }^{13} \mathrm{C}$ 
NMR (100 MHz, $\left.\mathrm{CDCl}_{3}\right) \delta 171.4(\mathrm{C}=\mathrm{O}$, ester), $171.2(\mathrm{C}=\mathrm{O}$, ester $), 167.0(\mathrm{C}=\mathrm{O}$, amide), $159.6(C-\mathrm{O}, \mathrm{Ar}), 135.0\left(C-\mathrm{CH}_{2}, \mathrm{Ar}\right), 134.8\left(C-\mathrm{CH}_{2}, \mathrm{Ar}\right), 128.3(C-\mathrm{C}=\mathrm{O}, \mathrm{Ar})$, $128.1(C-\mathrm{H}, \mathrm{Ar}), 127.2(C-\mathrm{H}, \mathrm{Ar}), 77.2$ (overlapped with $\left.\mathrm{CDCl}_{3}, \mathrm{OCH}_{2} \mathrm{CH}_{2}\right), 61.8$ $\left(\mathrm{OCH}_{2} \mathrm{CH}_{3}\right), 61.1\left(\mathrm{OCH}_{2} \mathrm{CH}_{3}\right), 49.3(\mathrm{NCH}), 36.5\left(\mathrm{CH}_{2} \mathrm{C}=\mathrm{O}\right), 31.2\left(\mathrm{Ar}-\mathrm{CH}_{2}-\mathrm{Ar}\right), 23.3$ $\left(\mathrm{OCH}_{2} \mathrm{CH}_{2}\right), 14.30\left(\mathrm{OCH}_{2} \mathrm{CH}_{3}\right), 14.25\left(\mathrm{OCH}_{2} \mathrm{CH}_{3}\right), 10.4\left(\mathrm{OCH}_{2} \mathrm{CH}_{2} \mathrm{CH}_{3}\right)$; IR (ATR) $\bar{v}_{\text {max }}\left(\mathrm{cm}^{-1}\right) 3347(\mathrm{~N}-\mathrm{H}), 1732(\mathrm{C}=\mathrm{O}$, ester $), 1657(\mathrm{C}=\mathrm{O}$, amide), $1197(\mathrm{C}-\mathrm{O})$. Anal. Calcd for $\mathrm{C}_{76} \mathrm{H}_{100} \mathrm{~N}_{4}: \mathrm{C}, 62.80 ; \mathrm{H}, 6.93 ; \mathrm{N}, 3.85 \%$. Found: $\mathrm{C}, 62.54 ; \mathrm{H}, 6.75 ; \mathrm{N}, 3.64 \%$.

4.2.2 Preparation of 25,26,27,28-tetra-n-propoxycalix[4]arene-5,11,17,23tetrakis-\{(2S)-2-[(carbonyl)amino]\}pentanedioic acid diethyl ester $(13 b)$

(a) The acid chloride (94) (519 mg, $0.62 \mathrm{mmol})$ was treated with a solution of Lglutamic acid diethyl ester hydrochloride (978 mg, $4.08 \mathrm{mmol})$ and triethylamine (1.40 $\mathrm{mL}, 10.5 \mathrm{mmol}$ ) as above, and allowed to stir at room temperature for six days. Workup, followed by chromatography (dichloromethane/ acetone $(9: 1, \mathrm{v} / \mathrm{v})$ and $0.5 \mathrm{v} / \mathrm{v} \%$ triethylamine) afforded a glassy yellow solid (320 mg, $0.21 \mathrm{mmol}, 34 \%$ yield) which crystallised on standing: mp $121-136{ }^{\circ} \mathrm{C}$ (material crystallised from glassy material); ${ }^{1} \mathrm{H}$ NMR $\left(400 \mathrm{MHz}, \mathrm{CDCl}_{3}\right) \delta 7.16(\mathrm{~d}, J=2.2 \mathrm{~Hz}, 4 \mathrm{H}, \mathrm{Ar}-H), 7.10(\mathrm{~d}, J=2.2 \mathrm{~Hz}, 4 \mathrm{H}, \mathrm{Ar}-$ $H$ ), $6.83(\mathrm{~d}, J=7.0 \mathrm{~Hz}, 4 \mathrm{H}, \mathrm{N}-H), 4.59$ (apparent dt, 4H, NCH), $4.46(\mathrm{~d}, J=13.6 \mathrm{~Hz}$, $\left.4 \mathrm{H}, \mathrm{H}_{\mathrm{ax}}, \mathrm{Ar}-\mathrm{CH}_{2}-\mathrm{Ar}\right), 4.27-4.15\left(\mathrm{~m}, 8 \mathrm{H}, \mathrm{OCH}_{2} \mathrm{CH}_{3}\right), 4.15-4.02\left(\mathrm{~m}, 8 \mathrm{H}, \mathrm{OCH}_{2} \mathrm{CH}_{3}\right)$, $3.38\left(\mathrm{t}, J=7.5 \mathrm{~Hz}, 8 \mathrm{H}, \mathrm{OCH}_{2} \mathrm{CH}_{2}\right), 3.26\left(\mathrm{~d}, J=13.6 \mathrm{~Hz}, \mathrm{H}_{\mathrm{eq}}, \mathrm{Ar}-\mathrm{CH}_{2}-\mathrm{Ar}\right), 2.50-2.34$ $\left(\mathrm{m}, 8 \mathrm{H}, \mathrm{CH}_{2} \mathrm{C}=\mathrm{O}\right), 2.31-2.17\left(\mathrm{~m}, 4 \mathrm{H}, \mathrm{H}^{\prime}, \mathrm{NCHCH}_{2}\right), 2.12-1.99\left(\mathrm{~m}, 4 \mathrm{H}, \mathrm{H}^{\prime \prime}, \mathrm{NCHCH}_{2}\right)$, 1.90 (sxt, $\left.J=7.5 \mathrm{~Hz}, 8 \mathrm{H}, \mathrm{OCH}_{2} \mathrm{CH}_{2}\right), 1.28\left(\mathrm{t}, J=7.1 \mathrm{~Hz}, 12 \mathrm{H}, \mathrm{OCH}_{2} \mathrm{CH}_{3}\right), 1.21(\mathrm{t}, J=$ 7.2 $\left.\mathrm{Hz}, 12 \mathrm{H}, \mathrm{OCH}_{2} \mathrm{CH}_{3}\right), 0.99\left(\mathrm{t}, J=7.5 \mathrm{~Hz}, 12 \mathrm{H}, \mathrm{OCH}_{2} \mathrm{CH}_{2} \mathrm{CH}_{3}\right) ;{ }^{13} \mathrm{C} \mathrm{NMR}$ $\left(100 \mathrm{MHz}, \mathrm{CDCl}_{3}\right) \delta 173.4(\mathrm{C}=\mathrm{O}$, ester $), 172.1(\mathrm{C}=\mathrm{O}$, ester $), 167.3(\mathrm{C}=\mathrm{O}$, amide $)$, 159.4 (C-O, Ar), $135.0\left(C-\mathrm{CH}_{2}, \mathrm{Ar}\right), 134.9\left(C-\mathrm{CH}_{2}, \mathrm{Ar}\right), 128.5(C-\mathrm{C}=\mathrm{O}, \mathrm{Ar}), 127.8$ 
(C-H, Ar), $127.7(C-\mathrm{H}, \mathrm{Ar}), 77.2$ (overlapped with $\mathrm{CDCl}_{3}, \mathrm{OCH}_{2} \mathrm{CH}_{2}$ ), 61.6

$\left(\mathrm{OCH}_{2} \mathrm{CH}_{3}\right), 60.7\left(\mathrm{OCH}_{2} \mathrm{CH}_{3}\right), 52.5(\mathrm{NCH}), 31.2\left(\mathrm{Ar}-\mathrm{CH}_{2}-\mathrm{Ar}\right), 30.6\left(\mathrm{CH}_{2} \mathrm{C}=\mathrm{O}\right), 27.4$

$\left(\mathrm{NCHCH}_{2}\right), 23.3\left(\mathrm{OCH}_{2} \mathrm{CH}_{2}\right), 14.30\left(\mathrm{OCH}_{2} \mathrm{CH}_{3}\right), 10.4\left(\mathrm{OCH}_{2} \mathrm{CH}_{2} \mathrm{CH}_{3}\right)$; IR (ATR) $\bar{v}_{\max }$ $\left(\mathrm{cm}^{-1}\right) 3382(\mathrm{~N}-\mathrm{H}), 1733(\mathrm{C}=\mathrm{O}$, ester $), 1645(\mathrm{C}=\mathrm{O}$, amide), $1190(\mathrm{C}-\mathrm{O})$. Anal. Calcd for $\mathrm{C}_{80} \mathrm{H}_{108} \mathrm{~N}_{4}: \mathrm{C}, 63.64 ; \mathrm{H}, 7.21 ; \mathrm{N}, 3.71 \%$. Found: $\mathrm{C}, 63.48 ; \mathrm{H}, 7.53 ; \mathrm{N}, 3.66 \%$.

(b) Dicyclohexylcarbodiimide (153 mg, $0.74 \mathrm{mmol}), N$-hydroxybenzotriazole (95 mg, $0.70 \mathrm{mmol})$, triethylamine $(0.25 \mathrm{~mL}, 1.8 \mathrm{mmol})$ and diethyl glutamate hydrochloride (454 mg, $1.89 \mathrm{mmol})$ were added to a solution of the calixarene acid (8) (107 mg, $0.14 \mathrm{mmol})$ in dichloromethane/dimethylformamide $(4: 1,10 \mathrm{~mL})$ and the reaction mixture stirred at room temperature $(48 \mathrm{~h})$. Dicyclohexylurea was removed by filtration and the filtrate treated with dilute hydrochloric acid $(10 \mathrm{~mL}$ of $0.5 \mathrm{M})$. The organic layer was then washed with water $(2 \times 20 \mathrm{~mL})$, dried $\left(\mathrm{Na}_{2} \mathrm{SO}_{4}\right)$ and concentrated. Chromatography (dichloromethane/acetone 9:1) then afforded 13b (86 $\mathrm{mg}, 41 \%)$ as a colourless glass.

(c) Triethylamine $(0.22 \mathrm{~mL}, 1.6 \mathrm{mmol})$ and diethyl glutamate hydrochloride (385 $\mathrm{mg}, 1.61 \mathrm{mmol})$ were added to a stirred suspension of the calixarene acid (8) (155 $\mathrm{mg}, 0.20 \mathrm{mmol})$ in dichloromethane $(15 \mathrm{~mL})$. When complete solublisation had occurred, $O$-(benzotriazol-1-yl)- $N, N, N^{\prime}, N^{\prime}$-tetramethyluronium hexafluorophosphate (416 mg, $1.1 \mathrm{mmol})$ and triethylamine $(0.22 \mathrm{~mL}, 1.6 \mathrm{mmol})$ were added and the reaction mixture stirred at room temperature $(6 \mathrm{~h})$. During the first 30 minutes the $\mathrm{pH}$ was checked frequently and triethylamine added as required to maintain it was approximately 8.5 . The reaction was quenched by the addition of hydrochloric acid (15 $\mathrm{mL}$ of $1 \mathrm{M}$ ), the organic layer separated, washed with sodium bicarbonate solution (15 $\mathrm{mL}$ of $5 \%)$ and brine $(15 \mathrm{~mL})$, dried $\left(\mathrm{Na}_{2} \mathrm{SO}_{4}\right)$ and concentrated. Chromatography (dichloromethane/acetone 9:1) then afforded $\mathbf{1 3 b}(160 \mathrm{mg}, 53 \%)$ as a colourless glass. 


\subsubsection{Preparation of 25,26,27,28-tetra-n-propoxycalix[4]arene-5,11,17,23-}

tetrakis-2, 2'-[(carbonyl)imino]diacetic acid diethyl ester (13c)

A solution of 2,2'-[(carbonyl)imino]diacetic acid diethyl ester hydrochloride $(1.27 \mathrm{~g}, 5.65 \mathrm{mmol})$ and triethylamine $(2.00 \mathrm{~mL}, 1.52 \mathrm{~g}, 15.0 \mathrm{mmol})$ dissolved in dichloromethane (15 mL) was added dropwise to a cold stirring solution of 9 (565 mg, $0.67 \mathrm{mmol})$ dissolved in dichloromethane $(10 \mathrm{~mL})$ over 15 minutes. The reaction mixture was stirred at room temperature under a nitrogen atmosphere over three days. The reaction mixture was diluted with dichloromethane $(25 \mathrm{~mL})$ and washed with hydrochloric acid ( $1 \mathrm{~m}, 3 \times 25 \mathrm{~mL})$, saturated sodium chloride $(25 \mathrm{~mL})$, dried $\left(\mathrm{Na}_{2} \mathrm{SO}_{4}\right)$, and concentrated in vacuo. Purification of the brown residue by column chromatography [dichloromethane/acetone $(9: 1, \mathrm{v} / \mathrm{v})]$ afforded a glassy yellow solid (296 mg, $0.20 \mathrm{mmol}, 30 \%$ yield) which crystallised on standing: $\mathrm{mp} 110-121{ }^{\circ} \mathrm{C}$ (material crystallised from glassy material); ${ }^{1} \mathrm{H}$ NMR $\left(400 \mathrm{MHz}, \mathrm{CDCl}_{3}\right) \delta 6.95(\mathrm{~s}, 8 \mathrm{H}$, $\mathrm{Ar}-H), 4.46\left(\mathrm{~d}, J=13.3,4 \mathrm{H}, \mathrm{H}_{\mathrm{ax}}, \mathrm{Ar}-\mathrm{CH}_{2}-\mathrm{Ar}\right.$ ), 4.33-4.07 (overlapped m, $\mathrm{OCH}_{2} \mathrm{CH}_{3}$ and $\mathrm{NCH}_{2}$ ), 3.90 (t, $\left.J=7.7 \mathrm{~Hz}, 8 \mathrm{H}, \mathrm{OCH}_{2} \mathrm{CH}_{2}\right), 3.17\left(\mathrm{~d}, J=13.3 \mathrm{~Hz}, 8 \mathrm{H}, \mathrm{H}_{\mathrm{eq}}, \mathrm{Ar}_{-} \mathrm{CH}_{2}-\right.$ Ar), 1.92 (sxt, $J=7.7 \mathrm{~Hz}, 8 \mathrm{H}, \mathrm{OCH}_{2} \mathrm{CH}_{2} \mathrm{CH}_{3}$ ), 1.27 (apparent br t, 24H, $\mathrm{OCH}_{2} \mathrm{CH}_{3}$ ), $0.99\left(J=7.7 \mathrm{~Hz}, 12 \mathrm{H}, \mathrm{OCH}_{2} \mathrm{CH}_{2} \mathrm{CH}_{3}\right) ;{ }^{13} \mathrm{C} \mathrm{NMR}\left(100 \mathrm{MHz}, \mathrm{CDCl}_{3}\right) \delta 171.6(\mathrm{C}=\mathrm{O})$, $169.6(\mathrm{C}=\mathrm{O}), 169.2(\mathrm{C}=\mathrm{O}), 158.3(C-\mathrm{O}, \mathrm{Ar}), 134.7\left(C-\mathrm{CH}_{2}, \mathrm{Ar}\right), 128.2(C-\mathrm{C}=\mathrm{O}, \mathrm{Ar})$, $128.3(\mathrm{C}-\mathrm{H}, \mathrm{Ar}), 61.7,61.1\left(\mathrm{OCH}_{2} \mathrm{CH}_{3}\right), 77.2$ (overlapped with $\mathrm{CDCl}_{3}, \mathrm{OCH}_{2} \mathrm{CH}_{2}$ ), 52.2, $48.1\left(\mathrm{NCH}_{2} \mathrm{C}=\mathrm{O}\right), 31.4\left(\mathrm{Ar}-\mathrm{CH}_{2}-\mathrm{Ar}\right), 23.2\left(\mathrm{OCH}_{2} \mathrm{CH}_{2} \mathrm{CH}_{3}\right), 14.5,14.3$

$\left(\mathrm{OCH}_{2} \mathrm{CH}_{3}\right), 10.4\left(\mathrm{OCH}_{2} \mathrm{CH}_{2} \mathrm{CH}_{3}\right)$; IR (ATR) $\bar{v}_{\max }\left(\mathrm{cm}^{-1}\right) 1738(\mathrm{C}=\mathrm{O}$, ester), 1645 $\left(\mathrm{C}=\mathrm{O}\right.$, amide), $1183(\mathrm{C}-\mathrm{O})$. Anal. Calcd for $\mathrm{C}_{76} \mathrm{H}_{100} \mathrm{~N}_{4}: \mathrm{C}, 62.80 ; \mathrm{H}, 6.93 ; \mathrm{N}, 3.85 \%$. Found: $\mathrm{C}, 62.80 ; \mathrm{H}, 7.00 ; \mathrm{N}, 3.68 \%$. 


\subsubsection{Preparation of 25,26,27,28-tetrapropoxycalix[4]arene-5,11,17,23-}

tetrakis-\{(2S)-2-[(carbonyl)amino]\}butanedioic acid (7a)

A solution of potassium carbonate $(350 \mathrm{mg}, 2.53 \mathrm{mmol})$ in water $(2 \mathrm{~mL})$ was added to a stirred solution of (13a) $(286 \mathrm{mg}, 0.20 \mathrm{mmol})$ in methanol $(25 \mathrm{~mL})$ at 40 $50{ }^{\circ} \mathrm{C}$. The reaction mixture was stirred for 2 hours, cooled to room temperature, and concentrated in vacuo. The residue was diluted with water $(30 \mathrm{~mL})$, acidified with hydrochloric acid ( $3 \mathrm{~m}, \sim 2 \mathrm{~mL})$ to $\mathrm{pH} \sim 1$, and extracted with ethyl acetate $(4 \times 15 \mathrm{~mL})$. The ethyl acetate extracts were combined, washed with water $(30 \mathrm{~mL})$ then saturated sodium chloride $(30 \mathrm{~mL})$, dried $\left(\mathrm{Na}_{2} \mathrm{SO}_{4}\right)$, and concentrated in vacuo. This gave a solid (160 mg, $0.13 \mathrm{mmol}, 66 \%$ yield): $\mathrm{mp}>240{ }^{\circ} \mathrm{C} \mathrm{dec} ;{ }^{1} \mathrm{H}$ NMR $\left(400 \mathrm{MHz}, \mathrm{CD}_{3} \mathrm{SOCD}_{3}\right) \delta$ 12.50 (br s, $5 \mathrm{H}, \mathrm{COOH}),{ }^{*} 8.74-8.24(\mathrm{~m}, 4 \mathrm{H}, \mathrm{N}-H), 7.59-7.19(\mathrm{~m}, 8 \mathrm{H}, \mathrm{Ar}-H), 4.74-$ $4.54(\mathrm{~m}, 4 \mathrm{H}, \mathrm{NCH}), 4.43,\left(\mathrm{~d}, J=12.9,4 \mathrm{H}, \mathrm{H}_{\mathrm{ax}}, \mathrm{Ar}-\mathrm{CH}_{2}-\mathrm{Ar}\right), 4.02-3.92(\mathrm{~m}, 4 \mathrm{H}$, $\mathrm{OCH}_{2}$ ), 3.36 (overlapped with $\mathrm{HOD}, \mathrm{H}_{\mathrm{eq}}, \mathrm{Ar}-\mathrm{CH}_{2}-\mathrm{Ar}$ ), 2.93-2.55 (m, $\mathrm{NCHCH}_{2} \mathrm{C}=\mathrm{O}$ ), 1.92 (sxt, $J=7.5 \mathrm{~Hz}, 8 \mathrm{H}, \mathrm{OCH}_{2} \mathrm{CH}_{2} \mathrm{CH}_{3}$ ), $1.04-0.90$ (m, $\left.12 \mathrm{H}, \mathrm{CH}_{3}\right) ;{ }^{13} \mathrm{C} \mathrm{NMR}$ $\left(100 \mathrm{MHz}, \mathrm{CD}_{3} \mathrm{SOCD}_{3}\right) \delta 172.6(\mathrm{C}=\mathrm{O}$, carboxylic acid $), 172.0(\mathrm{C}=\mathrm{O}$, carboxylic acid $)$, $165.7\left(\mathrm{C}=\mathrm{O}\right.$, amide), $158.7(C-\mathrm{O}, \mathrm{Ar}), 134.0\left(C-\mathrm{CH}_{2}, \mathrm{Ar}\right), 128.1$ (overlapped, $C-\mathrm{H}, \mathrm{Ar}$ and $C-\mathrm{C}=\mathrm{O}, \mathrm{Ar}), 76.7\left(\mathrm{OCH}_{2}\right), 49.3(\mathrm{NCH}), 35.9\left(\mathrm{CH}_{2} \mathrm{C}=\mathrm{O}\right), 30.7\left(\mathrm{Ar}-\mathrm{CH}_{2}-\mathrm{Ar}\right), 22.7$ $\left(\mathrm{OCH}_{2} \mathrm{CH}_{2}\right), 10.1\left(\mathrm{CH}_{3}\right)$; IR (ATR) $\bar{v}_{\text {max }}\left(\mathrm{cm}^{-1}\right) 3340(\mathrm{O}-\mathrm{H}), 1720(\mathrm{C}=\mathrm{O}$, carboxylic acid), $1626(\mathrm{C}=\mathrm{O}$, amide $), 1205(\mathrm{C}-\mathrm{O})$.

\subsubsection{Preparation of 25,26,27,28-tetra-n-propoxycalix[4]arene-5,11,17,23-} tetrakis-\{(2S)-2-[(carbonyl)amino]\}pentanedioic acid $(\mathbf{7 b})$

An aqueous solution of potassium hydroxide $(1.92 \mathrm{~m}, 925 \mu \mathrm{L}, 1.78 \mathrm{mmol})$ was added to a solution of $\mathbf{1 3 b}(320 \mathrm{mg}, 0.21 \mathrm{mmol})$ in methanol $(20 \mathrm{~mL})$ and stirred at room temperature for 6 hours. The reaction mixture was acidified with hydrochloric acid ( $3 \mathrm{~m}, \sim 1 \mathrm{~mL})$, concentrated in vacuo, and the residue was diluted with water 
$(10 \mathrm{~mL})$ and ethyl acetate $(10 \mathrm{~mL})$. The aqueous phase was separated and extracted with ethyl acetate $(3 \times 10 \mathrm{~mL})$. The ethyl acetate extracts were combined, washed with saturated sodium chloride $(20 \mathrm{~mL})$, dried $\left(\mathrm{Na}_{2} \mathrm{SO}_{4}\right)$, and concentrated in vacuo. This gave a yellow solid (273 mg, $0.21 \mathrm{mmol},>98 \%)$ : $\mathrm{mp} 121-140{ }^{\circ} \mathrm{C} ;{ }^{1} \mathrm{H} \mathrm{NMR}(400 \mathrm{MHz}$, $\left.\mathrm{CD}_{3} \mathrm{SOCD}_{3}\right) \delta 12.40(\mathrm{~b} \mathrm{~s}, 4 \mathrm{H}, \mathrm{COOH}),{ }^{*} 8.55-8.08(\mathrm{~m}, 4 \mathrm{H}, \mathrm{N}-H), 7.60-7.20(\mathrm{~m}, 8 \mathrm{H}$, $\mathrm{Ar}-H), 4.44\left(\mathrm{~d}, J=12.8 \mathrm{~Hz}, 4 \mathrm{H}, \mathrm{H}_{\mathrm{ax}}, \mathrm{Ar}-\mathrm{CH}_{2}-\mathrm{Ar}\right), 4.35-4.17(\mathrm{~m}, 4 \mathrm{H}, \mathrm{NCH}), 4.02-3.81$ (m, 8H, $\mathrm{OCH}_{2}$ ), 3.37 (overlapped with $\mathrm{HOD}, \mathrm{H}_{\mathrm{eq}}, \mathrm{Ar}-\mathrm{CH}_{2}-\mathrm{Ar}$ ), 2.45-2.27 (m, 8H, $\mathrm{CH}_{2} \mathrm{C}=\mathrm{O}$ ), 2.12-1.83 (overlapped m, $16 \mathrm{H}, \mathrm{NCHCH}_{2}$ and $\mathrm{OCH}_{2} \mathrm{CH}_{2}$ ), 1.06-0.90 (m, 12H, $\left.\mathrm{CH}_{3}\right) ;{ }^{13} \mathrm{C}$ NMR (100 MHz, $\left.\mathrm{CD}_{3} \mathrm{SOCD}_{3}\right) \delta 173.3$ (C=O, carboxylic acid), 172.9 $(\mathrm{C}=\mathrm{O}$, carboxylic acid $), 166.4(\mathrm{C}=\mathrm{O}$, amide $), 158.6(C-\mathrm{O}, \mathrm{Ar}), 134.0\left(C-\mathrm{CH}_{2}, \mathrm{Ar}\right)$, $128.3(C-\mathrm{C}=\mathrm{O}, \mathrm{Ar}), 128.1(\mathrm{C}-\mathrm{H}, \mathrm{Ar}), 76.7\left(\mathrm{OCH}_{2}\right), 52.1(\mathrm{NCH}), 30.6\left(\mathrm{Ar}-\mathrm{CH}_{2}-\mathrm{Ar}\right)$, $30.2\left(\mathrm{CH}_{2} \mathrm{C}=\mathrm{O}\right), 25.9\left(\mathrm{NCHCH}_{2}\right), 22.7\left(\mathrm{OCH}_{2} \mathrm{CH}_{2}\right), 10.1\left(\mathrm{CH}_{3}\right) ; \mathrm{IR}(\mathrm{ATR}) \bar{v}_{\max }\left(\mathrm{cm}^{-1}\right)$ $3352(\mathrm{O}-\mathrm{H}), 1731$ (C=O, carboxylic acid), 1633 (C=O, amide), $1202(\mathrm{C}-\mathrm{O})$.

\subsubsection{Preparation of 25,26,27,28-tetra-n-propoxycalix[4]arene-5,11,17,23-} tetrakis-2,2'-[(carbonyl)imino]diacetic acid (7c)

A solution of potassium carbonate $(212 \mathrm{mg}, 1.53 \mathrm{mmol})$ in water $(2 \mathrm{~mL})$ was added to a stirred solution of $13 \mathrm{c}(178 \mathrm{mg}, 0.12 \mathrm{mmol})$ in methanol $(25 \mathrm{~mL})$ at 40 $50{ }^{\circ} \mathrm{C}$. The reaction mixture was stirred for 2 hours, cooled to room temperature, and concentrated in vacuo. The residue was diluted with water $(30 \mathrm{~mL})$, acidified with hydrochloric acid $(3 \mathrm{~m}, \sim 1.5 \mathrm{~mL})$ to $\mathrm{pH} \sim 2$, and extracted with ethyl acetate $(4 \times 15 \mathrm{~mL})$. The ethyl acetate extracts were combined, washed with saturated sodium chloride (30 mL), dried $\left(\mathrm{Na}_{2} \mathrm{SO}_{4}\right)$, and concentrated in vacuo. This gave a solid (140 mg, $0.11 \mathrm{mmol}, 85 \%$ yield): $\mathrm{mp}>245{ }^{\circ} \mathrm{C} ;{ }^{1} \mathrm{H}$ NMR $\left(400 \mathrm{MHz}, \mathrm{CD}_{3} \mathrm{SOCD}_{3}\right) \delta 12.76$ (br s, $4 \mathrm{H}, \mathrm{COOH}),{ }^{*} 7.48-6.30(\mathrm{~m}, 8 \mathrm{H}, \mathrm{Ar}-H), 4.36\left(\mathrm{~d}, J=13.2 \mathrm{~Hz}, 4 \mathrm{H}, \mathrm{H}_{\mathrm{ax}}, \mathrm{Ar}-\mathrm{CH}_{2}-\mathrm{Ar}\right)$, 4.20-3.59 (overlapped m, 24H, $\mathrm{NCH}_{2}$ and $\mathrm{OCH}_{2}$ ), 3.28 (overlapped with $\mathrm{HOD}, \mathrm{H}_{\mathrm{eq}}$, 
$\left.\mathrm{Ar}-\mathrm{CH}_{2}-\mathrm{Ar}\right), 2.02-1.79\left(\mathrm{~m}, 8 \mathrm{H}, \mathrm{OCH}_{2} \mathrm{CH}_{2}\right), 1.14-0.79\left(\mathrm{~m}, 12 \mathrm{H}, \mathrm{CH}_{3}\right) ;{ }^{13} \mathrm{C} \mathrm{NMR}$

$\left(100 \mathrm{MHz}, \mathrm{CDCl}_{3}\right) \delta 170.3(\mathrm{C}=\mathrm{O}$, carboxylic acid $), 169.8(\mathrm{C}=\mathrm{O}$, amide $), 157.7(C-\mathrm{O}$, AR), $134.5\left(C-\mathrm{CH}_{2}, \mathrm{Ar}\right), 128.0(C-\mathrm{C}=\mathrm{O}, \mathrm{Ar}), 1272(C-\mathrm{H}, \mathrm{Ar}), 76.7\left(\mathrm{OCH}_{2}\right), 48.3$

$\left(\mathrm{NCH}_{2}\right), 30.4\left(\mathrm{Ar}-\mathrm{CH}_{2}-\mathrm{Ar}\right), 22.7\left(\mathrm{OCH}_{2} \mathrm{CH}_{2}\right), 10.1\left(\mathrm{CH}_{3}\right)$; IR (ATR) $\bar{v}_{\max }\left(\mathrm{cm}^{-1}\right) 3460$ $(\mathrm{O}-\mathrm{H}), 1725(\mathrm{C}=\mathrm{O}$, carboxylic acid $), 1196(\mathrm{C}-\mathrm{O})$.

\subsection{Calcium carbonate crystallisation experiments}

The impact of the synthesised crystal growth modifiers on the morphology of calcite was investigated using literature methods. $(40,47)$ Briefly, glass vials containing calcium chloride ( $7 \mathrm{mmol}, 20 \mathrm{~mL}$ ) with the appropriate concentration of additives and a microscope coverslip (10 $\mathrm{mm}$ diameter), were placed in a sealed desiccator $(20 \mathrm{~cm})$ along with a vial of ammonium carbonate. The vials were covered with Parafilm ${ }^{\circledR}$, with pinholes to allow the diffusion of ammonia and carbon dioxide. After seven days, the microscope coverslips were recovered and dried. After gold coating, the crystals were examined under a scanning electron microscope (Zeiss Evo 40XVP).

\subsection{Barium sulfate crystallisation experiments}

The impact of the synthesised additives on autonucleated desupersaturation rate and morphology of barium sulfate were investigated by literature methods. $(36,40)$ Briefly, barium chloride $\left(0.100 \mathrm{M}, 500 \mu \mathrm{L}\right.$, final $\mathrm{Ba}^{2+}$ concentration $\left.0.249 \mathrm{mM}\right)$ and the additive (as a solution, neutralised with sodium hydroxide) were added to milliQ water (200 mL) and allowed to equilibrate at $25^{\circ} \mathrm{C}$ while stirred. Equivalent sodium sulfate $(0.100 \mathrm{M}$, $500 \mu \mathrm{L}$ ) was added to initiate autonucleation and the conductivity meter (WTW model LF 197) set to measure (the data was recorded by a computer). After 3-5 hours, the reaction mixture was filtered through a $0.2 \mu \mathrm{m}$ filter membrane. If there was no decrease in the conductivity over the experiment period, the solution was placed in a 
vial with a microscope coverslip and allowed to crystallise for 5 to 14 days. Filter membranes and microscope coverslips were dried, gold coated, and the morphology examined under a scanning electron microscope (Zeiss Evo 40XVP). The desupersaturation rate was determined from the linear region of the desupersaturation curve.

Induction times were determined by a similar set-up to the desupersatuaration experiments. Barium chloride $\left(0.100 \mathrm{M}, 500 \mu \mathrm{L}\right.$, final $\mathrm{Ba}^{2+}$ concentration $\left.0.249 \mathrm{~mm}\right)$ and the additive (as a solution, neutralised with sodium hydroxide) were added to milliQ water $(200 \mathrm{~mL})$ and allowed to equilibrate at $25^{\circ} \mathrm{C}$ while stirred. Equivalent sodium sulfate $(0.100 \mathrm{M}, 500 \mu \mathrm{L})$ was added to initiate crystallisation. The reaction mixture was pumped through Masterflex ${ }^{\circledR}$ Tygon $^{\circledR}$ tubing (no. 14) by a Masterflex ${ }^{\circledR}$ L/S ${ }^{\circledR}$ Easy-Load ${ }^{\circledR}$ pump head (model $\left.7518-00\right)$ at $250 \mathrm{rpm}$ into a quartz flow cell. The absorbance at $900 \mathrm{~nm}$ was recorded by a GBC UV/VIS 916 spectrometer at $10 \mathrm{~s}$ intervals over 2 hours. The reaction mixture was filtered through a $0.2 \mu \mathrm{m}$ filter membrane. Filter membranes were dried, gold coated, and the morphology examined under a scanning electron microscope (Zeiss Evo 40XVP). Induction times were determined from graphs of absorbance versus time. 


\section{References}

(1) Song, R.-Q.; Cölfen, H., CrystEngComm 2011, 13, 1249-1276.

(2) Jones, F.; Ogden, M.I., CrystEngComm 2010, 12, 1016-1023.

(3) Jones, F.; Rohl, A.L.; Ogden, M.I.; Parkinson, G.M., Mater. Forum 2001, 25, $116-135$.

(4) Dove, P.M., Elements 2010, 6, 37-42.

(5) Addadi, L.; Weiner, S., Angew. Chem. Int. Ed. 1992, 31, 153-169.

(6) Behrens, P.; Baeuerlein, E., Handbook of Biomineralization: Biomimetic and Bioinspired Chemistry. Wiley-VCH GmbH and Co. KGaA: Weinheim, Germany, 2007; Vol. 2.

(7) Epple, M.; Baeuerlein, E., Handbook of Biomineralization: Medical and Clinical Aspects. Wiley-VCH GmbH and Co. KGaA: Weinheim, 2007; Vol. 3.

(8) Mann, S., Biomimetic Materials Chemistry. VCH Publishers, Inc.: New York, 1996.

(9) Xu, A.-W.; Ma, Y.; Cölfen, H., J. Mater. Chem. 2007, 17, 415-449.

(10) Gries, K.; Heinemann, F.; Gummich, M.; Ziegler, A.; Rosenauer, A.; Fritz, M., Cryst. Growth Des. 2011, 11, 729-734.

(11) Barthelat, F., Bioinspir. Biomim. 2010, 5, 035001.

(12) Heinemann, F.; Treccani, L.; Fritz, M., Biochem. Biophys. Res. Commun. 2006, 344, 45-49.

(13) Meyers, M.A.; Lin, A.Y.-M.; Chen, P.-Y.; Muyco, J., J. Mech. Behav. Biomed. Mater. 2008, 1, 76-85.

(14) Weiner, S., Calcif. Tissue Int. 1979, 29, 163-167.

(15) Gotliv, B.A.; Kessler, N.; Sumerel, J.L.; Morse, D.E.; Tuross, N.; Addadi, L.;

Weiner, S., ChemBioChem 2005, 6, 304-314.

(16) Suzuki, M.; Saruwatari, K.; Kogure, T.; Yamamoto, Y.; Nishimura, T.; Kato, T.; Nagasawa, H., Science 2009, 325, 1388-1390.

(17) Malkaj, P.; Dalas, E., Cryst. Growth Des. 2004, 4, 721-723.

(18) Manoli, F.; Dalas, E., J. Cryst. Growth 2001, 222, 293-297.

(19) Wu, C.; Wang, X.; Zhao, K.; Cao, M.; Xu, H.; Xia, D.; Lu, J.R., Cryst. Growth Des. 2011, 11, 3153-3162.

(20) Elhadj, S.; De Yoreo, J.J.; Hoyer, J.R.; Dove, P.M., Proc. Natl. Acad. Sci. U. S. A. 2006, 103, 19237-19242.

(21) Piana, S.; Jones, F.; Gale, J.D., CrystEngComm 2007, 9, 1187-1191.

(22) Chen, S.-F.; Yu, S.-H.; Wang, T.-X.; Jiang, J.; Cölfen, H.; Hu, B.; Yu, B., Adv. Mater. 2005, 17, 1461-1465.

(23) Song, R.-Q.; Xu, A.-W.; Antonietti, M.; Cölfen, H., Angew. Chem. Int. Ed. 2009, 48, 395-399.

(24) Sonnenberg, L.; Luo, Y.; Schlaad, H.; Seitz, M.; Cölfen, H.; Gaub, H.E., J. Am. Chem. Soc. 2007, 129, 15364-15371.

(25) Volkmer, D.; Fricke, M., Z. Anorg. Allg. Chem. 2003, 629, 2381-2390.

(26) Volkmer, D.; Fricke, M.; Agena, C.; Mattay, J., CrystEngComm 2002, 4, 288295.

(27) Volkmer, D.; Fricke, M.; Agena, C.; Mattay, J., J. Mater. Chem. 2004, 14, 2249-2259.

(28) Volkmer, D.; Fricke, M.; Vollhardt, D.; Siegel, S., J. Chem. Soc., Dalton Trans. 2002, 4547-4554.

(29) Fricke, M.; Volkmer, D.; Krill, C.E.; Kellermann, M.; Hirsch, A., Cryst. Growth Des. 2006, 6, 1120-1123. 
(30) Volkmer, D., Biologically Inspired Crystallization of Calcium Carbonate Beneath Monolayers: A Critical Overview. In Handbook of Biomineralization:

Biomimetic and Bioinspired Chemistry; Behrens, P., Bäeuerlein, E., Eds. Wiley-VCH GmbH and Co. KGaA: Weinheim, 2008; Vol. 2, pp 65-87.

(31) Fricke, M.; Volkmer, D., Top. Curr. Chem. 2007, 270, 1-41.

(32) Meldrum, F.C.; Fendler, J.H., Construction of Organized Particulate Films by the Langmuir-Blodgett Technique. In Biomimetic Materials Chemistry; Mann, S., Ed. VCH Publishers, Inc.: New York, 1996; pp 175-219.

(33) DiMasi, E.; Kwak, S.-Y.; Pichon, B.P.; Sommerdijk, N.A.J.M., CrystEngComm 2007, 9, 1192-1204.

(34) Baynton, A.; Radomirovic, T.; Ogden, M.I.; Raston, C.L.; Richmond, W.R.; Jones, F., CrystEngComm 2011, 13, 109-112.

(35) Jones, F.; Clegg, J.; Oliveira, A.; Rohl, A.L.; Ogden, M.I.; Parkinson, G.M.; Fogg, A.M.; Reyhani, M.M., CrystEngComm 2001, 3, 165-167.

(36) Jones, F.; Oliveira, A.; Rohl, A.L.; Parkinson, G.M.; Ogden, M.I.; Reyhani, M.M., J. Cryst. Growth 2002, 237-239, 424-429.

(37) Massi, M.; Ogden, M.I.; Radomirovic, T.; Jones, F., CrystEngComm 2010, 12, 4205-4207.

(38) Heywood, B.R.; Ovens, A.C.D., MRS Proceedings 2006, 923, 0923-V09050909.

(39) Bartlett, M.J.; Mocerino, M.; Ogden, M.I.; Oliveira, A.; Parkinson, G.M.; Pettersen, J.K.; Reyhani, M.M., J. Mater. Sci. Technol. 2005, 21, 1-5.

(40) Jones, F.; Mocerino, M.; Ogden, M.I.; Oliveira, A.; Parkinson, G.M., Cryst. Growth Des. 2005, 5, 2336-2343.

(41) Sansone, F.; Barboso, S.; Casnati, A.; Fabbi, M.; Pochini, A.; Ugozzoli, F.; Ungaro, R., Eur. J. Org. Chem. 1998, 1998, 897-905.

(42) Baldini, L.; Sansone, F.; Faimani, G.; Massera, C.; Casnati, A.; Ungaro, R., Eur. J. Org. Chem. 2008, 2008, 869-886.

(43) Baldini, L.; Sansone, F.; Scaravelli, F.; Casnati, A.; Ungaro, R., Supramol. Chem. 2010, 22, 776-788.

(44) Ihli, J.; Bots, P.; Kulak, A.; Benning, L.G.; Meldrum, F.C., Adv. Funct. Mater. 2013, 23, 1965-1973.

(45) Azab, H.A.; Al-Deyab, S.S.; Anwar, Z.M.; Ahmed, R.G., J. Chem. Eng. Data 2011, 56, 833-849.

(46) Freeman, S.R.; Jones, F.; Ogden, M.I.; Oliviera, A.; Richmond, W.R., Cryst. Growth Des. 2006, 6, 2579-2587.

(47) Gower, L.A.; Tirrell, D.A., J. Cryst. Growth 1998, 191, 153-160.

(48) Gehrke, N.; Cölfen, H.; Pinna, N.; Antonietti, M.; Nassif, N., Cryst. Growth Des. 2005, 5, 1317-1319.

(49) Politi, Y.; Mahamid, J.; Goldberg, H.; Weiner, S.; Addadi, L., CrystEngComm 2007, 9, 1171-1177.

(50) Fu, G.; Qiu, S.; Orme, C.; Morse, D.; De Yoreo, J.J., Adv. Mater. 2005, 17, 2678-2683.

(51) Fu, G.; Valiyaveettil, S.; Wopenka, B.; Morse, D.E., Biomacromolecules 2005, $6,1289-1298$.

(52) Zhang, Z.; Gao, D.; Zhao, H.; Xie, C.; Guan, G.; Wang, D.; Yu, S.-H., J. Phys. Chem. B 2006, 110, 8613-8618.

(53) Wang, X.; Kong, R.; Pan, X.; Xu, H.; Xia, D.; Shan, H.; Lu, J.R., J. Phys. Chem. B 2009, 113, 8975-8982.

(54) Klepetsanis, P.G.; Dalas, E.; Koutsoukos, P.G., Langmuir 1999, 15, 1534-1540. 
(55) Marin, F.; Luquet, G., Unusually Acidic Proteins in Biomineralization. In Handbook of Biomineralization: Biological Aspects and Structure Formation;

Bäeurlein, E., Ed. Wiley-VCH Verlag GmbH: Weinheim, 2008; Vol. 1, pp 273-290.

(56) Mann, S.; Didymus, J.M.; Sanderson, N.P.; Heywood, B.R.; Samper, E.J.A., J. Chem. Soc., Faraday Trans. 1990, 86, 1873-1880.

(57) Addadi, L.; Weiner, S., Proc. Natl. Acad. Sci. U. S. A. 1985, 82, 4110-4114.

(58) Jones, F.; Jones, P.; Ogden, M.I.; Richmond, W.R.; Rohl, A.L.; Saunders, M., J. Colloid Interface Sci. 2007, 316, 553-561.

(59) Heywood, B.R.; Mann, S., J. Am. Chem. Soc. 1992, 114, 4681-4686.

(60) Heywood, B.R.; Mann, S., Adv. Mater. 1994, 6, 9-20.

(61) Yang, K.C.; Hogg, R., Anal. Chem. 1979, 51, 758-763.

(62) Mullin, J.W., Crystallization; 4th ed.; Elsevier: London, 2004.

(63) Armarego, W.L.F.; Chai, C.L.L., Purification of Laboratory Chemicals; 5th ed.; Elsevier: Sydney, 2003.

(64) Brady, O.L.; Elsmie, G.V., Analyst 1926, 51, 77-78.

(65) Fulmer, G.R.; Miller, A.J.M.; Sherden, N.H.; Gottlieb, H.E.; Nudelman, A.;

Stoltz, B.M.; Bercaw, J.E.; Goldberg, K.I., Organometallics 2010, 29, 2176-2179.

(66) Gottlieb, H.E.; Kotlyar, V.; Nudelman, A., J. Org. Chem. 1997, 62, 7512-7515. 